\title{
Anticholesterol Activity of Okra Fruit Extract (Abelmoschus esculentus (L) Moench) and Its Nanoemulsion in Vivo
}

\author{
Ratna Djamil ${ }^{1}$ *, Deni Rahmat ${ }^{2}$, Sarah Zaidan², Maya Nur latifah ${ }^{3}$
}

Ratna Djamil1,*, Deni Rahmat², Sarah Zaidan ${ }^{3}$, Maya Nur latifah ${ }^{3}$

'Laboratory of Phytochemistry, Faculty of Pharmacy, Pancasila University, Jakarta, 12640 INDONESIA.

${ }^{2}$ Laboratory ofTechnology Pharmacy, Faculty of Pharmacy, Pancasila University, Jakarta, 12640 INDONESIA.

${ }^{3}$ Laboratory of Pharmacology, Faculty of Pharmacy, Pancasila University, Jakarta, 12640 INDONESIA.

\section{Correspondence}

\section{Ratna Djami}

Laboratory of Phytochemistry, Faculty of Pharmacy, Pancasila University, Jakarta,12640 INDONESIA.

E-mail: ratnadjamilffup@gmail.com

History

- Submission Date: 12-12-2019;

- Review completed: 26-12-2019;

- Accepted Date: 19-01-2020.

DOI : 10.5530/pj.2020.12.50

Article Available online http://www.phcogj.com/v12/i2

\section{Copyright}

(C) 2020 Phcogj.Com. This is an openaccess article distributed under the terms of the Creative Commons Attribution 4.0 International license.

\section{ABSTRACT}

Background: Okra fruit has phytosterol, pectin that has the potential as an anticholesterol Objective: The purpose of this study was to obtain $70 \%(\mathrm{v} / \mathrm{v})$ ethanol extract of okra fruit and its nanoparticles and to evaluate their anti-cholesterol activity in vivo. Material and Methods: Okra fruit was extracted by kinetic maceration and the produced extract was tested for phytochemical screening and anti-cholesterolemi activity in vivo. The nanoparticles was prepared using a cosolvention method. In this study, DDY white mice was divided into 5 groups, namely normal control, negative control, positive control (simvastatin), the extract (400 $\mathrm{mg} / \mathrm{kg} \mathrm{BW}$ ), and the nanoparticles ( $400 \mathrm{mg} / \mathrm{kg} \mathrm{BW}$ ) group. All groups except normal were fed for 14 days with high cholesterol diet. After 14 days, the induction of hypercholesterolemia was stopped and simvastatin was administrated to positive control and the test groups were treated with the extract and the nanoparticles for 7 days. Measurement of total cholesterol level was carried out by cholesterol stripe test method. Results: The nanoparticles used demonstrated particle size of $134.7 \mathrm{~nm}$ and zeta potential of -26.72 . The results showed a decrease in total cholesterol levels in positive control, the extract and the nanoparticles group as many as $48.68 \% ; 32.44 \%$ and $42.95 \%$, respectively. Conclusion: The nanoparticles can increase the activity of the extract.

Key words: Abelmoschus esculentus L. Moench, Hypercholesterolemia, Nanoparticles, Okra fruits, Total cholesterol level.

\section{INTRODUCTION}

Cardiovascular diseases, especially coronary heart and blood vessels are known as the cause of deaths in Indonesia. Consuming foods which are rich in cholesterol give rise degenerative diseases including coronary heart disease (CHD) and cardiovascular disease. CHD results from high cholesterol diets such as fatty foods, coconut milk and various fried foods. Hypercholesterolemia is a disorders in fat metabolism characterized by high level of total cholesterol in the blood. The formation of fat clots in blood vessels emerges a risk of atherosclerosis. ${ }^{1,2}$

One of the therapies that can be used by people in Indonesia is herbal medicines. Soluble fibers found in okra (Abelmoschus esculentus (L.) Moench) can reduce cholesterol level thus lower the possibility of cardiovascular disease. Okra fruit contains pectin which can reduce high blood cholesterol by modifying the formation of bile in the intestine. The content of other substances found in okra are vitamin C, phytosterols, and flavonoids. Phytosterols in okra which can be found in plant cell membranes have a structure similar to cholesterol but they can dissolve in water. Hence, they are able to interact with cholesterol in blood vessels. ${ }^{3,4}$

In previous studies okra seeds given for 42 days in 2 different doses to mice suffering from hypercholesterolemia resulted in a decrease in serum LDL cholesterol by $40.50 \%$ and $53.63 \%{ }^{5}$ It was also mentioned that the effect of okra extract on HMG-CoA activity in mice showed a significant decrease in hypercholesterolemia. ${ }^{6}$ One of the weaknesses of extracts is its low solubility in water thus reduce the bioavailability of their active compounds. The application of nanotechnology provides a number of advantages. Particle size and surface characteristics of nanoparticles can be modified to control the release of active compounds during the delivery of active compound and to improve the penetration through biological membranes. ${ }^{7}$ Therefore, it was the aim of this study to formulate okra fruit extract into nanoemulsion to obtain a better anti-cholesterol activity.

\section{MATERIAL AND METHODS}

\section{Material}

Okra fruit (Abelmoschus esculentus (L.) Moench), propylene glycol, simvastatin tablet, sodium carboxymethylcellulose. sucrose, capmul, glicerine.

\section{Extraction}

The extract was obtained by extracting the simplicia powder with kinetic maceration method using $70 \%(\mathrm{v} / \mathrm{v})$ ethanol, the maserate obtained was then concentrated with a rotary evaporator until a thick extract was obtained.

\section{Phytochemical screening}

Phytochemical screening is a chemical compounds study of the simplicia and the extract of okra fruit including identification of flavonoid, steroid and triterpenoid, saponin and coumarin groups. ${ }^{8,9}$ 


\section{Nanoemulsion extract preparation}

Nanoemulsion of okra fruit extract was prepared by the cosolvent method. The extract was dissolved in cosolvent consisting of capmul, propylen glycol, glycerin and aquadest. The optimal formula contained $100 \mathrm{mg}$ of $70 \%$ (v/v) ethanol extract of okra fruit, $1 \mathrm{ml}$ capmul, $2.5 \mathrm{ml}$ propylene glycol, $2 \mathrm{ml}$ glycerin, and $10 \mathrm{ml}$ distilled water. ${ }^{10}$

\section{Anticholesterol study}

In this study, DDY male mice divided into 5 groups, namely normal, negative, positive (simvastatin), the extract ( $400 \mathrm{mg} / \mathrm{kg} \mathrm{BW})$, and the nanoparticles $(\sim 400 \mathrm{mg} / \mathrm{kg} \mathrm{BW})$. All groups except normal group were given hypercholesterol-inducing diet for 14 days. Afterwards, simvastatin, the extract and the nanoparticles were given for 7 days. Measurement of total cholesterol levels was carried out by the cholesterol strip test method.

\section{RESULTS AND DISCUSSION}

\section{Extraction}

$885.25 \mathrm{~g}$ of okra simplicia were extracted by kinetic maceration using 40 L 70\%(v/v) ethanol. After evaporation by a vacuum rotary evaporator, $88.26 \mathrm{~g}$ thick extract was obtained.

\section{Phytochemical Screening}

The simplicia of okra fruit and the extract contained flavonoids, steroids, triterpenoids, saponins and coumarin.

\section{Nanoemulsion extract preparation}

The generated nanoemulsion demonstrated particle size of $134.7 \mathrm{~nm}$, polydispersity index of 0.512 and zeta potential of $-26.72 \mathrm{mV}$ (Figures $1 \& 2)$.

\section{Anticholesterol study}

Measurement of body weight of mice was carried out during the study to investigate the influence of the treatment during 21 days. Measurement of body weight of mice on day 0 was carried out to determine the body weight of mice before the treatment to ensure the body weight of mice used in accordance with the criteria for experimental animals used (20-30 gr). Table 1 shows the average body weight of the mice used that meets the requirements $(20.68 \pm 0.65$ $24.94 \pm 1.07 \mathrm{gr})$.

Measurement of body weight of mice on day $21^{\text {st }}$ was carried out to determine whether there was a decrease in body weight of mice after being given treatment. The results showed that the average body weight of mice ranged from $28.18 \pm 2.80-32.66 \pm 2.22$ gr. Based on the results of the statistical analysis, the normality test (Shapiro-Wilk test) showed that the difference in body weight on day $14^{\text {th }}$ up to $21^{\text {st }}$ was normally distributed. On day $21^{\text {st }}$ there was a decrease in body weight in the

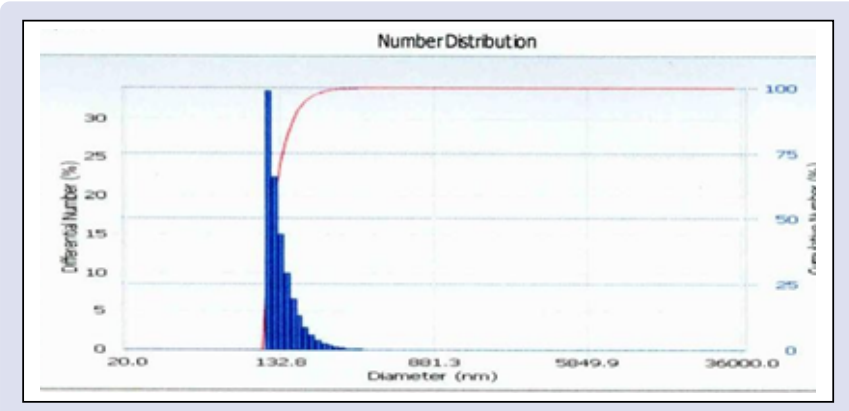

Figure 1: Particle size of Nanoemulsion.

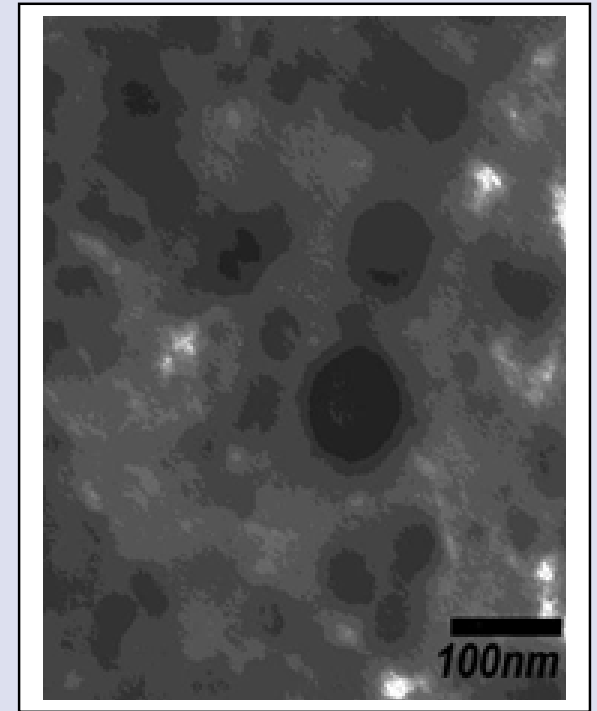

Figure 2: Morphology of Nanoemulsion.

extract and the nanoparticles group. There is a positive correlation between body weight with cholesterol, VLDL and LDL levels. However, positive group did not result in weight loss because statin therapy can increase calorie and fat intake, ${ }^{11,12}$ thus weight loss caused by changes in lipid profile did not occur in this group.

\section{Measurement of total cholesterol levels in mice}

Measurement of total cholesterol levels on day 0 was carried out to find out the total cholesterol levels before treatment (initial conditions). The data showed that the average total cholesterol level of blood of mice under normal conditions in the range of $55.4 \pm 6.58 \mathrm{mg} / \mathrm{dL}-66.2 \pm 3.03$ $\mathrm{mg} / \mathrm{dL}$. The total cholesterol level on day 0 fulfilled the requirements for normal total blood cholesterol in mice $(40-130 \mathrm{mg} / \mathrm{dL})$. The total cholesterol level on day 0 among groups I, II, III, IV, and V was no significant difference (Table 1).

Measurement of total cholesterol levels on day $14^{\text {th }}$ was carried out to determine whether the total cholesterol levels in group II, III, IV, and V increased after being given a food inducing hypercholesterolemia. The data in Table II shows that the average blood cholesterol level in mice groups II, III, IV, V, and VI ranged from $149.8 \pm 8.98 \mathrm{mg} / \mathrm{dL}-155.2 \pm$ $8.84 \mathrm{mg} / \mathrm{dL}$. However, there were no significant differences among the groups (Table 2).

Measurement of total cholesterol levels on day $21^{\text {st }}$ shows a decrease in total cholesterol levels in mice group III, IV and V. There were significant differences in total cholesterol levels on day $21^{\text {st }}$ among group I, II, III, IV and V, which means there are significant differences among the group. In this study, statistical analysis was performed on the difference in total blood cholesterol levels before and after treatment, which is between day 0 and day $14^{\text {th }}$ and between day $14^{\text {th }}$ and day $21^{\text {st }}$ (Table 3).

The results of statistical tests show that there were significant differences between the extract and the nanoparticles group. Therebye, the nanparticles has the ability to lower total blood cholesterol levels better than the extract. This could be caused by the characteristics of nanoemulsion which has a very small particle size and low interface tension so that it can easily penetrate. In addition, nanoemulsion has long-term stability (without creaming, sedimentation, flocculation or coalescence) due to thermodynamic stability. ${ }^{13,14}$ 
Table 1: The Body Weight of Mice on Day 0.

\begin{tabular}{cccccc}
\hline $\begin{array}{c}\text { Mice } \\
\text { Number }\end{array}$ & I & II & III & IV & V \\
\cline { 2 - 6 } & 24.2 & 20.3 & 24.3 & 22.1 & 23.7 \\
2 & 23.7 & 20.7 & 23.1 & 21.4 & 25.1 \\
3 & 22.6 & 20.4 & 23.1 & 23.7 & 24.0 \\
4 & 23.3 & 20.2 & 24.0 & 25.7 & 26.2 \\
5 & 22.7 & 21.8 & 21.7 & 22.7 & 25.7 \\
Average & 23.3 & 20.68 & 23.24 & 23.12 & 24.94 \\
SD & 0.67 & 0.65 & 1.01 & 1.67 & 1.07 \\
\hline
\end{tabular}

I : Normal group

II : Negative group

III : Positive group

IV : The extract group

$\mathrm{V}$ : The nanoemulsion group

Table 2: Cholesterol Level on Day $14^{\text {th }}$.

\begin{tabular}{cccccc}
\hline \multirow{2}{*}{ Mice Number } & I & II & Cholesterol Level (mg/dL) & IV & V \\
\cline { 2 - 6 } & 61 & 148 & 151 & 158 & 163 \\
2 & 66 & 145 & 163 & 143 & 152 \\
3 & 58 & 155 & 145 & 145 & 142 \\
4 & 69 & 165 & 147 & 161 & 163 \\
5 & 59 & 163 & 150 & 142 & 146 \\
Average & 62.6 & 155.2 & 151.2 & 149.8 & 153.2 \\
SD & 4.72 & 8.84 & 7.01 & 8.98 & 9.63 \\
\hline
\end{tabular}

I : Normal group

II : Negative group

III : Positive group

IV : The extract group

$\mathrm{V}$ : The nanoemulsion group

Table 3: Cholesterol Level on Day $21^{\text {st }}$.

\begin{tabular}{llllll}
\hline \multirow{2}{*}{ Mice Number } & \multicolumn{2}{l}{ Cholesterol Level $(\mathbf{m g} / \mathbf{d L})$} & & IV & V \\
\cline { 2 - 6 } & I & II & III & 105 & 80 \\
1 & 65 & 145 & 78 & 96 & 75 \\
2 & 64 & 140 & 78 & 98 & 70 \\
3 & 60 & 150 & 81 & 107 & 76 \\
4 & 65 & 160 & 80 & 100 & 72 \\
5 & 55 & 165 & 77,6 & 101,2 & 74,6 \\
Average & 71,8 & 152 & 3.91 & 4.66 & 3.85 \\
SD & 4.32 & 10.37 & & & \\
\hline
\end{tabular}

I: Normal group

II : Negative group

III : Positive group

IV:The extract group

$\mathrm{V}$ : The nanoemulsion group

\section{DISCUSSION}

In this study, okra fruit extracts and the nanoemulsion were tested for their anticholesterol activity. Compounds in okra fruit extract that act as anticholesterol agents are steroids (phytosterol) and pectin. For this reason, the selection of methods and solvents is a matter that must be considered. The method used for extracting in this study is maceration. Maceration was chosen because it is the simplest and safest method that prevents the destruction of compounds which are not stable on heating. The solvent used for maceration is $70 \%(\mathrm{v} / \mathrm{v})$ ethanol. Steroids which are polar compounds can be extracted using $70 \%(\mathrm{v} / \mathrm{v})$ ethanol. Phytochemical screening of the simplicia and the extract were carried out to determine the content of secondary metabolites found in okra fruit. The results displayed both the simplicia and the extract contained secondary metabolites including flavonoids, steroids, saponins and coumarin.
In this study, simvastatin was chosen as a standar reference because simvastatin is an inhibitor of the HMG-CoA enzyme. The enzyme catalyzes the formation of mevalonates from HMG CoA which is the initial stage of cholesterol formation. Where one of the okra fruit extracts that can provide cholesterol-reducing effects is pectin. Weight measurement and determination of total blood cholesterol levels of mice were performed on day $0^{\text {th }}, 14^{\text {th }}$, and $21^{\text {st }}$ respectively. In this study, the anti-cholesterol activity of the extract and the nanoemulsion were compared. On day $14^{\text {th }}$, the average growth rate of mice is 1 gram / day. The growth rate of animals is influenced by species, individuals, sex, age, feeding, and diet consumed. ${ }^{11}$ In the negative, positive, low, moderate, and high doses there was a significant increase in body weight on days $0-14$. Weight gain can be caused by an increase in the amount of fat deposited in adipose tissue, especially those under the skin and the abdominal cavity. ${ }^{12}$ 
The anticholesterol activity test consists of 5 groups: group I is used as a normal control without receiving any treatment in order to find out whether there were other effects that could influence the total blood cholesterol levels. However, until the end of the experiment mice showed a normal total blood cholesterol level with an average level of 40-130 mg / dL. Group II was used as a negative control induced by high cholesterol diet given orally without any other treatment. On day $14^{\text {th }}$, the mice in group II experienced an increase in body weight and in total cholesterol levels with an average level of $155.2 \mathrm{mg} / \mathrm{dL}$ and only experienced a slight decrease on day $21^{\text {st }}$ with an average level of 152 $\mathrm{mg} / \mathrm{dL}$. Hence, after the treatment of high cholesterol diet for 14 days mice were in hypercholesterolemia condition.

Group IV and V were used as test groups induced hypercholesterolemic diets for 14 days before treatment, after hypercholesterolemia, on day $15^{\text {th }}$ the mice were treated with both the extract at a dose of $400 \mathrm{mg} / \mathrm{kgBW}$ and the nanoemulsion at a dose which was equal to $400 \mathrm{mg} / \mathrm{kg} \mathrm{BW}$ of the extract. The extract and the nanoemulsion lowered the total cholesterol level with an average level of $101.2 \mathrm{mg} / \mathrm{dL}$ and $74.6 \mathrm{mg} / \mathrm{dL}$, respectively On day $21^{\text {st. }}$. This demonstrated both the extract and the nanoemulsion could reduce the total cholesterol level. The nanoemulsion was considered to deliver the active compunds in the body and permeate through biological membranes easier compared to the extract alone.

\section{CONCLUSION}

The nanoemulsion formed by mixing propylene glycol, capmul and glycerine could entrapped the extract and reduced the total blood cholesterol level lower compared to the extract alone in hypercholesterolemic mice. Accordingly, this formulation could be developed for its pharmaceutical dosage form with effective therapheutic effect.

\section{REFERENCES}

1. Arianti R. Pengaruh Fraksi Air Kelopak Bunga Rosella (Hibiscus sabdariffa L.) Terhadap Kadar Kolesterol Darah Tikus Putih Jantan Hiperkolesterol Dan Hiperkolesterol Disfungsi Hati Tesis. Sumatera Barat Universitas Andalas; 2011;11-2.

2. Devinda. Nyoman Kertia. Panjang Umur dengan kontrol kolesterol dan asam urat.Yogyakarta; 2012;75-6.

3. Ngoc T, Ngo N, Van T, Phung V. Hypolipidemic effect of extracts from Abelmoschus esculentus L. (Malvaceae) on Tyloxapol-induced hperlipidemia in mice. Warasan Phesatchasat. 2008;38:42-6.

4. Sabitha V, Ramachandran S, Naveen KR, Panneerselvam K. Antidiabetic and antihyperlipidemic potential of Abelmoschus esculentus (L.) Moench. in streptozotocin-induced diabetic rats. J Pharm Bioallied Sci. 2011;3(3):397-402.

5. Poorva D, Sunita M. Effect of okra seed in reduction of cholesterol. Journal of Entomology and Zoology Studies. 2017;5(4):94-7.

6. Esan AM, Olaiya, Charles, Sameer V, Elango K, Dhanabal SP. Antihyperlipidemic And Glucose Lowering Effect of Extract Of Bioregulator Treated Okra (Abelmoschus Esculentus L.) Fruits in Triton-Induced Hyperlipidemia Rats. IOSR Journal of Pharmacy and Biological Sciences. 2017;12:39-50.

7. Singh SM, Prasad S, Gambhir SI. Nanotechnology in medicine and antibacterial effect of silver nanoparticles. Digest Journal of Nanomaterials and Biostructures. 2008:3;115-22

8. Yadav Hemant KS, Nagavarma BVN, Ayaz A, Vasudha LS, Shivakumar HG Different Techniques for Preparation of Polymeric Nanoparticles. Asian Journal of Pharmaceutical and Clinical Research. 2012; 5(3):16-23.

9. Prashant T, Blemish K, Mandeep K, Gurpreet K, Harleen K. Phytochemical screening and Extraction: A Review. Internatiional Pharmaceutica Science. 2011.

10. Ankit K, Akhlesh K, Ritesh V. Formulation and Evaluation of Polymeric Nanoparticles of an Antiviral Drug for Gastroretention. International Journal of Pharmaceutical Sciences and Nanotechnology. 2012;4:1557-62.

11. Sanlier N, Yabanci N. Relationship between Body Mass Index, Lipids and Homocysteine levels in university students. J Pak Med Assoc. 2007;57:491-5.

12. Sugiyama T, Tsugawa Y. Different Time Trends of Caloric and Fat Intake between Statin-users and Non-users among US Adults. JAMA Intern Med. 2014;174(7):1038-45.

13. Yin W. Plasma lipid profiling across species for the identification of optimal animal models of human dyslipidemia. J Lipid Res. 2012;53(1):5.

14. Vauthier C. Core-Shell Polymer Nanoparticle Formulation for the Ora Administration of Peptides and Proteins. New york: Drug Delivery Research Advances. Nova science Publishers. 2007:48.

\section{GRAPHICAL ABSTRACT}
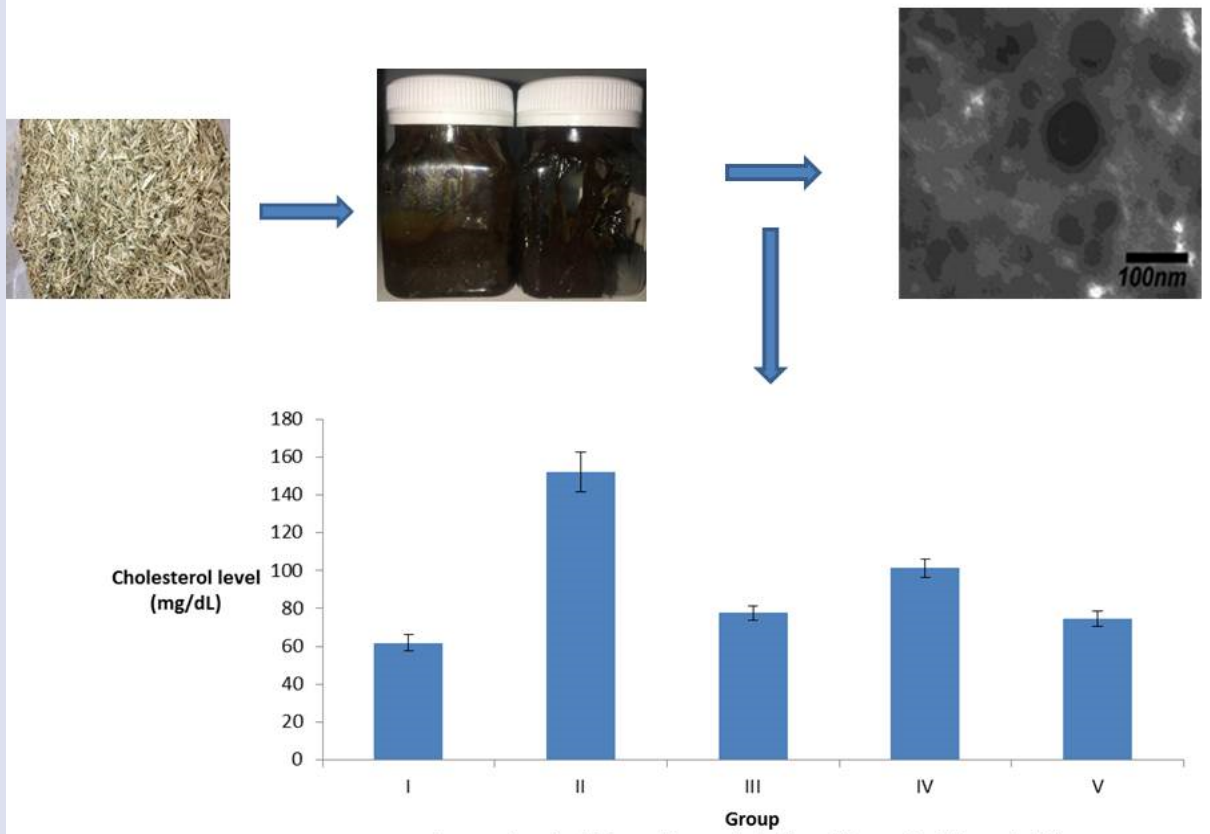
IV=the extract $(400 \mathrm{mg} / \mathrm{kg} \mathrm{BW}), \mathrm{V}=$ the nanoparticles $(\sim 400 \mathrm{mg} / \mathrm{kg} \mathrm{BW})$ 


\section{ABOUT AUTHORS}

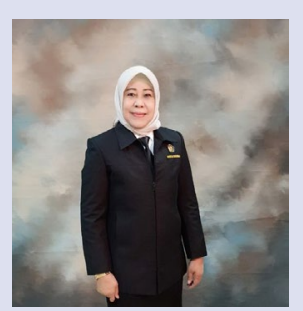

Dr. Ratna Djamil obtained her PhD from Department of Chemistry, Universitas Indonesia. Her research focuses on phytochemistry and she has published a lot of articles from her work in natural products. Her current research interests include natural products and their applications on hypercholesterolemia and diabetic treatments. She is currently a senior lecturer and a senior scientist in Universitas Pancasila, Jakarta, Indonesia. She is a member of Indonesian Association of Herbal Medicine Scientist (PERHIPBA).

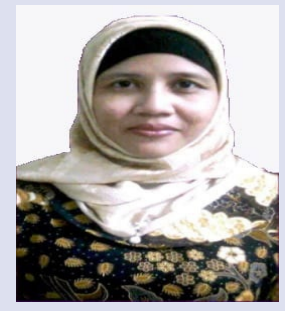

Sarah Zaidan is a PhD student in the department of pharmacology, Universitas Pancasila, Jakarta, Indonesia. Her current research work is focused on mechanism of antioxidant and anticholesterol of natural product. She has coauthored some publications. She also works in Hospital as a senior pharmacist and a member of Indonesian Pharmasists Association.

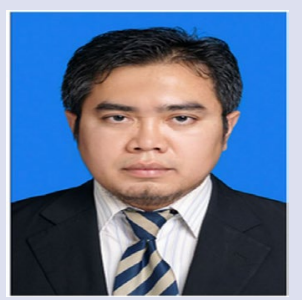

Dr. Deni Rahmat obtained his PhD in 2012 from Innsbruck University, Austria. He is currently a lecturer in the department of pharmaceutical technology, Universitas Pancasila, Jakarta, Indonesia and the chairman of International Conference of Pharmaceutical Nanotechnology/Nanomedicine Indonesia. He has contributed in the field of pharmaceutical nanotechnology in Indonesia and authored a lot of publications.

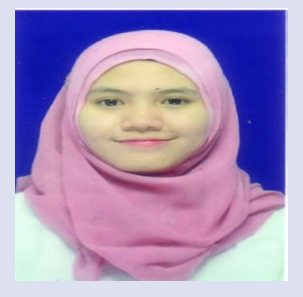

Maya Nur Latifah obtained her bachelor's degree in 2018 from Faculty of Pharmacy, Universitas Pancasila, Jakarta, Indonesia. She is a research assistant in Phytochemistry Laboratory, Faculty of Pharmacy, Universitas Pancasila. Her current research work is on formulation of natural product.

Cite this article: Djamil R, Rahmat D, Zaidan S, Latifah MN. Anticholesterol Activity of Okra Fruit Extract (Abelmoschus esculentus (L) Moench) and Its Nanoemulsion in Vivo. Pharmacog J. 2020;12(2):316-20. 